\title{
Editorial
}

\section{Os Desafios do Tempo Presente}

A edição da Revista Laborare que estamos apresentando reflete a gravidade do momento que se enfrenta. Um momento de crise acerca do que deve representar o Estado e de como devem agir suas instituições. O Direito do Trabalho está no centro dessa crise, pois regula a relação social fundante, aquela que permite ou impede a sobrevivência física. É por meio do trabalho remunerado que em uma sociedade como a nossa se obtém o dinheiro necessário para comprar comida, vestir e morar. Então, quem não tem trabalho não tem, no limite, condições de sobreviver. O reconhecimento dessa realidade, assim como a tensão causada pelos movimentos de trabalhadores e a própria necessidade do sistema de que haja consumo, exigiu ao longo dos anos a construção de teias de proteção social. O Direito do Trabalho revelou-se como o limite da exploração possível, como bem demonstra artigo publicado nessa edição.

Nosso modelo de organização social funda-se na propriedade privada e na assimilação de tudo, inclusive pessoas (força de trabalho) e recursos naturais à condição de mercadoria a ser negociada. Sem a convicção de que somos proprietários da força de trabalho, talvez nos revoltássemos com o fato de que o acesso à comida, roupa, remédio ou casa só se dá, em regra, através do dinheiro que se obtém pela troca de trabalho por salário. Um salário que só existe se a propriedade privada (força de trabalho) for negociada no mercado. É justamente o Direito do Trabalho que revela, com mais nitidez, que o que aparece como exercício da liberdade de trabalhar é, na realidade, trabalho obrigatório, na medida em que constitui condição para a sobrevivência física. Eis porque é tão grave todo o movimento que há décadas busca esvaziar o conceito de vínculo de emprego e que nesta revista é enfrentado no artigo que trata da uberização do trabalho. 
O que hoje vivemos não é apenas a crise dessa compreensão histórica da necessidade de impor limites à troca entre capital e trabalho. É a imposição de uma nova ordem, na qual trabalho infantil, violência contra a mulher e outras questões, que pensávamos superadas, voltam a ser defendidas por pessoas que ocupam cargos públicos. Daí porque é tão importante a discussão travada nos artigos sobre as repercussões da pandemia no contrato de aprendizagem e sobre o trabalho da mulher. Velhos temas tão insistemente presentes em um país que já atinge a trágica cifra de 14,8 milhões de desempregados. Segundo os dados do primeiro trimestre de 2021, divulgados pelo IBGE, já são 86,7 milhões trabalhadores informais. Pessoas que trocam trabalho por salário, mas não tem o vínculo reconhecido, não fruem férias, não podem adoecer, porque se não trabalham nada recebem, embora as contas do mês, com as quais garantem casa e comida, sigam chegando.

As questões trazidas nos artigos aqui reunidos são, em verdade, feridas nunca tratadas de uma história de desrespeito aos direitos mais elementares de quem vive do trabalho. E ganham uma profundidade dolorida a partir do momento em que, diante da crise de 2008 e sem saber como lidar com a reação social de 2013, inicia-se um processo de fragilização do compromisso com a ordem constitucional de 1988, que tem como ponto de referência simbólica o golpe que retira do poder a primeira mulher eleita Presidenta da República. Romper com o respeito ao direito liberal de voto, retirando justamente uma mulher do cargo, sob um discurso que mira exclusivamente em um partido dos trabalhadores e, portanto, também no metalúrgico que antes ocupou a Presidência, é a caricatura do que somos: um país fundado sob a lógica patriarcal, autoritária e racista.

Em uma tal sociedade, fazer valer direitos sociais é um grande desafio. Por isso, nesses pouco mais de trinta anos que nos separam da Constituição de 1988 nunca conseguimos, nem mesmo sob o governo de um partido dos trabalhadores, fazer valer efetivamente o direito de proteção contra a despedida, o direito à repartição adequada da renda e da terra, o direito ao emprego decente. As fórmulas precarizantes que hoje são identificadas a partir do neologismo da uberização sempre estiveram presentes. 
Não há dúvida, porém, que o desrespeito se aprofunda quando o discurso oficial se desconecta completamente do pacto firmado em 1988. Eis a profundidade da crise que hoje enfrentamos e que está bem representada pelas legislações que vêm sendo editadas durante a pandemia, cujo conteúdo precariza mais e mais, desfigura mais e mais o Direito do Trabalho, inclusive no que se refere à destruição das normas de segurança e saúde no trabalho. A tais legislações soma-se uma jurisprudência avessa à proteção social. A discussão que se trava no artigo que trata da uberização do trabalho nos auxilia a compreender o drama social que mal se esconde nessas opções políticas de desamparar cada vez mais o povo brasileiro.

É certo que esse não é um movimento que se circunscreve à realidade brasileira, nem tampouco poderá ser enfrentado, sem que haja uma profunda reflexão e revisão inclusive do nosso ensino jurídico. Para auxiliar na indicação de caminhos possíveis para o tensionamento e a mudança que se impõe como urgente nesse quadro, temos também nessa edição um artigo que trata da importância de um estudo crítico do Direito do Trabalho, a partir de experiências de extensão universitária.

Uma experiência de leitura que nos fará seguir firmes na esperança de superação dessa etapa sombria da nossa história recente. Outros desafios, talvez ainda mais trágicos, já foram enfrentados pela classe trabalhadora e por quem lida com o Direito do Trabalho no Brasil. A leitura e a reflexão sobre os temas jurídicos aqui reunidos é já, sem dúvida, um modo saudável de atuar politicamente, no sentido mais amplo e positivo que essa palavra pode alcançar.

Boa leitura!

\section{Os Editores}

